\title{
粉体・金属間接触電位差測定モデルの検討
}

\author{
板 倉 隆 行*, 野 村 俊 之*, 増 田 弘 昭*
}

\section{Examination of the Contact-potential-difference Measurement Model between a Powder and a Metal}

by

Takayuki ITAKURA $^{\dagger}$, Toshiyuki NOMURA ${ }^{\dagger}$ and Hiroaki MASUDA ${ }^{\dagger}$

Key Words : Contact Potential Difference, Codenser Model, Work Function

\section{1. 緒 言}

粉体の製造，生成も含めて種々の乾式操作を行う と，それに付随して粉体の帯電が起こるため, 製造工 程中の各種トラブルの原因となる場合が極めて多い。 一方，電子写真や粉体塗装などの分野では，粉体の帯 電を積極的に利用している。このような粉体材料にお いては，帯電特性の制御が最終製品の品質上，極めて 重要な因子となる。電子写真におけるトナ一の場合 は, 各種染料, 顔料や表面処理剤によって帯電を制御 しているが，その処方に関しては経験に基づいた試行 錯誤の上，決定されているのが現状である。いずれに しても，粉体の帯電に起因するトラブルを防止し，か つ，積極的に利用するためには，粉体の帯電特性を定 量的に評価する方法を確立することが必要不可欠であ る。

本報では, 同一粒子径で組成(仕事関数)の異なる 2 種類の高分子系粉体を試料として用い, 既報 ${ }^{14)} に お ~$ ける粉体・金属間接触電位差測定モデルを実験的に検 証することによって，モデルの修正を行うとともに理 論式を新たに導出した。なお，接触電位差測定装置の 構成については前報 ${ }^{21} に$ 詳しく揭載されているのでこ

\section{4年 7月 7日受付}

粉体工学会春期研究発表会(1994年5月，京都)にて一部発表

* 京都大学工学部化学工学教室

( ₹606-01 京都市左京区吉田本町)TEL。 075-753-5565

$\dagger$ Dept. of chem. Eng., Kyoto Univ.,

(Yoshida-Honmachi, Sakyo-ku, Kyoto 606-01)
こでは省略する。

\section{2. 試料粉体}

試料粉体としては，質量中位径 $88 \mu \mathrm{m} ，$ 比重 4.8 の電 子写真用二成分現像剤に用いられるフェライトキャリ ア(同和鉄粉社製)を用い, 流動床法によってフェライ トコア表面に樹脂を $0.5 \mathrm{wt} \%$ コーティングした。コー ティング樹脂としては，アミノシラン系シリコーン （信越化学社製）とフッ化ビニリデン(ダイキン工業社 製)の 2 種類を用いた。以後簡単のため, 前者のコ一 ティング試料をパウダー $\mathrm{A}$ ，後者のコーテイング試料 をパウダーBと記すことにする。なお，コーティング によって，質量中位径はほとんど変化していない。

\section{3. 測定モデルの実験的検証と修正}

従来より，モデルにおける接触電位差の測定箇所に 関して不明な点が多かった。そこで本報ではその点を 明確化するために 2 種類の粉体を用い，充填方法を変 えた実験を行うことによって測定箇所の特定を行っ た。

実験ではFig. 1の断面概略図に示すような 4 タイプ に粉体試料を充填し，その直後からの接触電位差の経 時変化を測定した。その結果をFig. 2に示す。ここ で, 接触電位差が時間に対して変化するのは, 前報2) で報告したように粉体の初期体積電荷が緩和するため である。この体積電荷の紘和過程における測定值が見 掛けの接触電位差 $V_{0}{ }^{\prime}$ であり，緩和後の定常值が粉体 


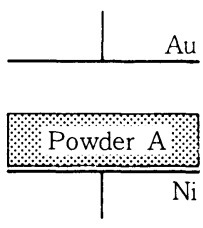

(a) Type-1

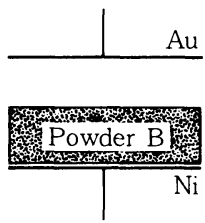

(c) Type-3

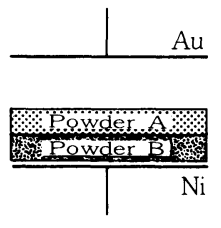

(b) Type-2

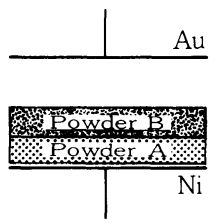

(d) Type- 4
Fig. 1 Cross-sectional view of powder layer

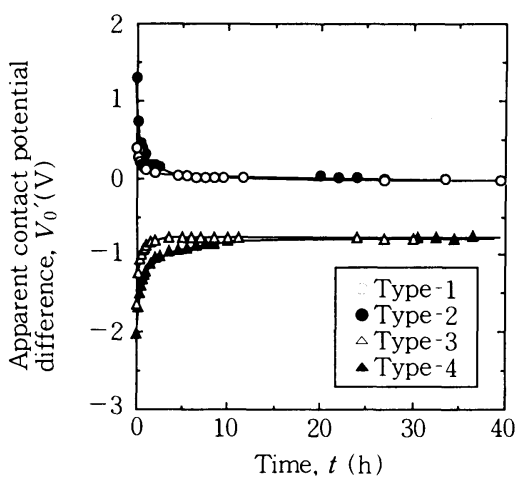

Fig. 2 Change of contact potential difference with time

固有の接触電位差 $V_{0}$ (基準電極に対する有効仕事関数 の差)を表わす。この結果より, Tyep-1とTyep-2, Type- 3 とType- 4 が同じ接触電位差 $V_{0}$ を示しているこ とがわかる。よって, 定常值は粉体層上部に存在する 物質に依存していることが明らかである。

以下に述べるモデルではFig. 2の実駼結果を考虑し て, 接触電位差は上部電極 $(\mathrm{Au})$ を基準とした粉体層

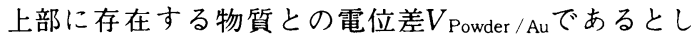
た。さらにこのモデルでは, 粉体試料が誘電体である 場合の分極を考慮に入れて検討した。

\section{1 粉体扈が 1 種類の場合 (Tyep-1，3)}

Fig. 3(a)に粉体層が 1 種類であるType-1の電気回 路を示し，Fig. 3(b)にコンデンサーモデルを示す。 ここで，図中における $\rho_{\mathrm{a}}$ は粉体層 $\mathrm{A}$ の体積電荷密度， $\varepsilon_{0}$ は空間層の誘電率, $\varepsilon_{\mathrm{a}}$ は粉体層 $\mathrm{A} の$ 見掛けの誘電率を 表わす。このモデルに示した 2 個の直列コンデンサー は, 下から粉体層 $\mathrm{A}$ と空間層を表す。また 3 個の電池 はそれぞれ，下部電極 $(\mathrm{Ni})$ に粉体 $\mathrm{A}(\mathrm{PA})$ が接触する ことによって生じる電位差 $V_{\mathrm{PA} / \mathrm{Ni}}$, その下部電極

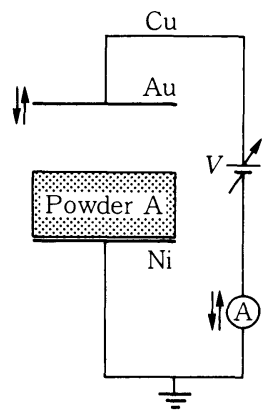

(a) Electric circuit

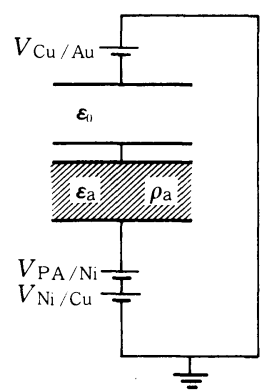

(b)Condenser model
Fig. 3 Electric circuit and condenser model for single powder layer

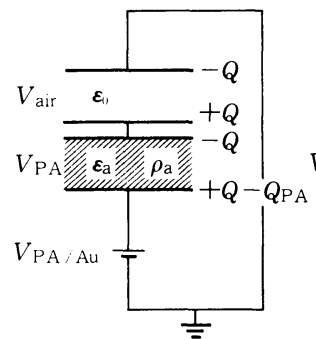

(a) Before measurement

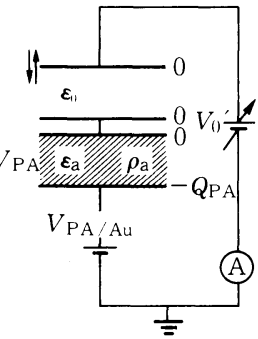

(b)During measurement
Fig. 4 The condenser model for single powder layer with volumetric charge

$(\mathrm{Ni})$ が回路を形成する銅線 $(\mathrm{Cu})$ に接触することによ って生じる電位差 $V_{\mathrm{Ni}} / \mathrm{Cu}$, 及びその銅線 $(\mathrm{Cu})$ が上部電 極 $(\mathrm{Au})$ に接触することによって生じる電位差 $V_{\mathrm{Cu}} / \mathrm{Au}$ を表す。そして，3 個の電池が起電力となって各コン デンサーに電荷が誘起されている様子をFig. 4(a)に 示す。なお， 3 個の起電力に関して電位には加算性が 成立するので, 次式のようにまとめて表現することが できる。

$$
V_{\mathrm{PA} / \mathrm{Ni}}+V_{\mathrm{Ni} / \mathrm{Cu}}+V_{\mathrm{Cu} / \mathrm{Au}}=V_{\mathrm{PA} / \mathrm{Au}}
$$

すなわち, Eq. (1)の接触電位差 $V_{\mathrm{PA} / \mathrm{Au}}$ が起電力とな つて各々のコンデンサーに電荷が誘起される。ここで 電荷は, 誘電体である粉体の分極と体積電荷QPA 虑して決定した。

続いてFig. 4(b)に，測定時におけるコンデンサー モデルを示す。上部電極が上下振動することによっ て, 上部のコンデンサーに相当する空間層の静電容量 が時間変化するため, 回路全体に変位電流が流れる。 しかし, 可変直流電源によって電位 $V_{\text {air }}$ を打ち消すだ けの電圧 $V_{0}{ }^{\prime}$ を印加したとき, 回路には変位電流が流 れない。そのとき次式が成立する。 


$$
V_{0}{ }^{\prime}=V_{\mathrm{PA}}+V_{\mathrm{PA} / \mathrm{Au}}
$$

以上より，粉体層 $\mathrm{A} か ゙$ 帯電しているときの見掛けの 接触電位差(印加電圧) $V_{0}{ }^{\prime}$ は, 粉体層 $\mathrm{A} の$ 体積電荷に よる電位 $V_{\mathrm{PA}}$ と起電力 $V_{\mathrm{PA} / \mathrm{Au}}$ の和に等しいことがわか る。

従来の理論では, 境界条件において回路を形成する 銅線 $(\mathrm{Cu})$ に対する粉体 $\mathrm{A}(\mathrm{PA})$ の電位差 $V_{\mathrm{PA} / \mathrm{Cu}}$ と, 上 部電極 $(\mathrm{Au})$ に対する銅線の電位差 $V_{\mathrm{Cu} / \mathrm{Au}}$ の両項を考 慮していなかった。そこでこの点を考慮して, 既報” と同様に空間層と粉体層にガウスの定理を適用する と, 粉体層Aが帯電しているときの見掛けの接触電位 差 $V_{0}{ }^{\prime}$ は次式で表される。

$$
V_{0}^{\prime}=\frac{\rho_{\mathrm{a}}}{2 \varepsilon_{\mathrm{a}}} a_{1}^{2}+V_{\mathrm{PA} / \mathrm{Au}}
$$

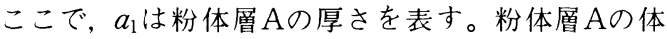
積電荷が完全に緩和したとき $\rho_{\mathrm{a}}$ はゼロになるので, そ のときの接触電位差 $V_{0}$ は次式で表される。

$$
V_{0}=V_{\mathrm{PA} / \mathrm{Au}}
$$

\section{2 粉体層を積み重ねた場合(Type-2, 4)}

粉体層を上下 2 段に積み重ねたFig. 1 における Type-2の電気回路をFig. 5(a)に示し, コンデンサー モデルをFig. 5(b)に示す。この場合におけるTypeととの相違は, 粉体 $\mathrm{A}$ 粉体Bが接触することによって 生じる電位差 $V_{\mathrm{PA} / \mathrm{PB}}$ が起電力として加わっている点 である。よって, 粉体層 $\mathrm{A}-\mathrm{B}$ 間の接触電位差 $V_{\mathrm{PA} / \mathrm{PB}}$ と他の電池をType-1と同様にしてまとめた $V_{\mathrm{PB} / \mathrm{Au}}$ が 起電力となって電荷が誘起される。この場合における 測定時の印加電圧 $V_{0}$ 'は次式のように表現できる。

$$
\begin{aligned}
V_{0}{ }^{\prime} & =V_{\mathrm{PA}}+V_{\mathrm{PA} / \mathrm{PB}}+V_{\mathrm{PB}}+V_{\mathrm{PB} / \mathrm{Au}} \\
& =V_{\mathrm{PA}}+V_{\mathrm{PB}}+V_{\mathrm{PA} / \mathrm{Au}}
\end{aligned}
$$

次に，理論式に関しても前節と同様に誘導すると， 粉体層 $\mathrm{A}, \mathrm{B}$ が帯電しているときの見掛けの接触電位 差 $V_{0}{ }^{\prime}$ は次式で表される。

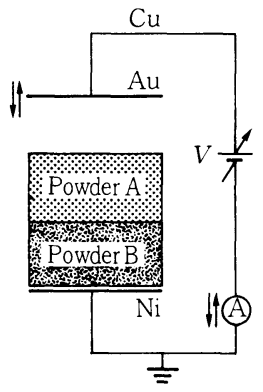

(a) Electric circuit

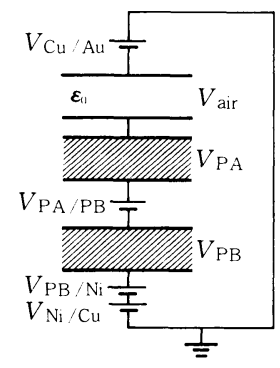

(b) Condenser model
Fig. 5 Electric circuit and condenser model for two powder layers in series

$$
V_{0}^{\prime}=\frac{\rho_{\mathrm{a}}}{2 \varepsilon_{\mathrm{a}}} a_{1}^{2}+\frac{\rho_{\mathrm{a}}}{\varepsilon_{\mathrm{a}}} a_{1} a_{2}+\frac{\rho_{\mathrm{b}}}{2 \varepsilon_{\mathrm{b}}} a_{2}^{2}+V_{\mathrm{PA} / \mathrm{Au}}
$$

ここで， $a_{2}$ は粉体層Bの厚さを表す。この場合も粉 体層 $\mathrm{A}, \mathrm{B}$ の体積電荷が完全に緩和したときの接触電 位差 $V_{0}$ は前出のEq. (4)で表される。

これらの結果より, 本装置は上部電極の物質と, 対 向面に存在する物質が仮に接触したときの電位差(接 触電位差)を, 起電力の合計值として間接的に測定し ているといえる。すなわち, Voltaの法則をはじめと した金属・金属間における接触電位差の概念が金属・ 誘電体間においても適用できることを示している。

\section{4. 結 言}

接触電位差の測定に関して, 同一粒子径で組成 (仕 事関数)の異なる 2 種類の高分子系粉体を用いた実験 を行うと共に，コンデンサーモデルに基づいた理論的 検討を行った。その結果, 測定される接触電位差は電 極間の物質にかかわらず，上部電極を基準とした粉体 層上部に存在する物質の接触電位差であることが理論 的，実験的に明らかになった。

\begin{tabular}{|c|c|c|c|c|}
\hline \multirow{3}{*}{$\begin{array}{ll}a_{1}, & a_{2} \\
\varepsilon_{\mathrm{a}}, & \varepsilon_{\mathrm{b}}\end{array}$} & : thickness of powder layer & $(\mathrm{m})$ & $V_{0}{ }^{\prime}$ & : apparent contact potential difference \\
\hline & : apparent dielectic constant of po & der layer & $V_{0}$ & : contact potential difference \\
\hline & & $\left(\mathrm{F} \cdot \mathrm{m}^{-1}\right)$ & $V_{\mathrm{Ni} / \mathrm{Cu}}$ & : potential of $\mathrm{Ni}$ against $\mathrm{Cu}$ \\
\hline$\varepsilon_{0}$ & : dielectric constant of air & $\left(\mathrm{F} \cdot \mathrm{m}^{-1}\right)$ & $V_{\mathrm{Cu} / \mathrm{Au}}$ & al of $\mathrm{Cu}$ against $\mathrm{Au}$ \\
\hline$Q$ & : charge & (C) & $V_{\mathrm{PA} / \mathrm{Au}}$ & : potential of powder-A against $\mathrm{Au}$ \\
\hline$Q_{\text {PA }}$ & : charge of powder $-\mathrm{A}$ & (C) & $V_{\text {air }}$ & : potential of space \\
\hline$\rho_{\mathrm{a}}, \rho_{\mathrm{b}}$ & : charge density of powder layer & $\left(\mathrm{C} \cdot \mathrm{m}^{-3}\right)$ & $V_{\mathrm{PA}}$ & : potential of powder-A \\
\hline$V_{\text {Powd }}$ & : potential of powder against $\mathrm{Au}$ & $(\mathrm{V})$ & $V_{\mathrm{PA} / \mathrm{Ni}}$ & : potential of powder-A against $\mathrm{Ni}$ \\
\hline
\end{tabular}

[謝辞］接触電位差測定装置を試作していただい た三協パイオテク株式会社に謝意を表します。また， 測定用試料の試作に協力していただいた三田工業株式 会社の川田秀明氏と河野信明氏に謝意を表します。

\section{Nomenclature}


$V_{\mathrm{PA} / \mathrm{PB}}:$ potential of powder-A against powder-B (V)

$V_{\mathrm{PB} / \mathrm{Ni}}$ : potential of powder-B against $\mathrm{Ni}$
$V_{\mathrm{PB} / \mathrm{Au}}:$ potential of powder-B against $\mathrm{Au}$

(V) $\quad V_{\mathrm{PB}} \quad$ : potential of powder-B

\section{References}

1) Yoshida, H., T. Fukuzono and H. Masuda : $J$. Soc. of Powder Tech., Japan, 28, 226(1991)

2) Masuda, H., T. Itakura, K. Gotoh, T. Takahashi and T. Teshima : J. Soc. of Powder Tech., Japan, 30, 854(1993)

3) Yoshida, H., T. Fukuzono, H. Ami, Y. Iguchi, and H. Masuda : J. Soc. of Powder Tech., Japan, 29, 504(1992)

4) Yoshida, H., Y. Iguchi, T. Matsumoto, H. Masuda, H. Murata and Y. Yamada : J. Soc. of Powder Tech., Japan, 30, 330(1993) 